\title{
EFFECTS OF PROCUREMENT RELATED FACTORS ON CONSTRUCTION PROJECT PERFORMANCE IN NIGERIA OGUNSANMI, O.E. \\ http://dx.doi.org/10.4314/ejesm.v6i2.12
}

\author{
Received 8th February 2013; accepted 4th March 2013
}

\begin{abstract}
Several Literatures in construction management support the view that procurements have impacts on project performance. Aim of this study is to investigate the effects of procurement related factors of procurement selection criteria, tendering methods and variation orders on project performance. Purpose of the study is to evaluate the effects of procurement related factors on project performance. Snowballing sampling technique was used in selecting forty (40) construction organizations in Lagos metropolitan city that participated in the study and thirty-one (31) responses were secured from Architects, Builders, Engineers and Quantity Surveyors. Results of the study indicate that procurement selection criteria of cost, time, quality, project characteristics and external environmental factors have effects on project performance. Competitive, open and selective tendering methods have high impacts on project performance. No significant difference was found between the impacts of tendering methods on project performance. Variation orders impact project performance with time, cost overruns and disputes and it have effects on project performance. Conclusions are that procurement selection criteria, tendering methods and variation orders have impacts on project performance. Cost, time, quality related factors, tendering methods and variation orders strongly affect project performance. Recommendations to clients, stakeholders, practitioners and consultants are on the onset to consider tendering methods, use selective, open and competitive tendering approaches and discourage excessive variation orders during construction. Policy makers in government, clients, and private developers into housing projects should give adequate attention for selecting appropriate procurement and tendering methods for better management of future projects in Nigeria and other developing countries.
\end{abstract}

Key words: Procurement, Construction project, Performance, Nigeria

\section{Introduction}

Different studies have confirmed the use of various types of procurement methods for project delivery in Nigeria. Studies of Ogunsanmi, Iyagba and Omirin (2003), Ojo, Adeyemi and Fagbenle (2006), and Dada (2012) all confirm the use of Traditional, Design and Build, Project Management, Construction Management, Labouronly, Direct Labour and other types such as Alliancing, Partnering and Joint Ventures procurements in the Nigerian construction industry. The use of these procurement methods can significantly affect the performance of most projects. In construction management Literature several studies have also indicated that procurement systems have significant effects on construction project performance. Noted in this direction are studies of Eriksson and Westerberg (2012), Eriksson and Vennstrom (2012), Rasid, Taib, Ahmed, Nasid, Ali and Zainordin (2006) Hashim (1999) and Miller Furneaux, Davis, Love and O'Donnel (2009). Eriksson and Westerberg (2012) study postulates different procurement factors at the design, bid invitation, bid evaluation and sub-contractor selections stages that can have various influences on project performance.

Similarly, Eriksson and Vennstrom (2012) also investigates the effects of cooperative procurement procedures of joint specification, limited bid invitation, soft evaluation parameters, collaborative tools and others on project performance in the Swedish construction industry. In the same vein, study of Rasid et al. (2006) indicates that different procurement methods offer different allocation of responsibilities, activities sequencing, process and procedure and organizational approach that would affect project performance. It appears that these different studies have exploited the effects of different procurement factors peculiar to their construction industry on project performance. Moreover, different procurement methods have been used in 
the Nigerian construction industry to procure several construction projects and these procurement methods can also influence project performance. There are few studies in Nigeria that have investigated the effects of procurement methods on project performance.

Worthy of note in the use of these different procurement methods in Nigeria is that they offer different procurement factors in respect of their selection criteria, tendering methods, variation order, contract system, inherent risks and management of relationships between parties on a project that can affect project performance. This present study investigates the effects of these procurement factors on construction project performance in Nigeria. Objective of this study is to investigate the effects of procurement selection factors, tendering methods and variation order factors on project performance. Project performance factors considered in this study are cost, time and quality. This study is significant in that it provides an insight into the variants of procurement methods in use in Nigeria, the types of procurement factors that can affect project performance and it also contributes to procurement Literature in investigating the effects of procurement methods on construction project performance.

\section{Procurement Related Factors that Influence Project Performance}

Previous studies of Hashim (1999), Rasid et al. (2006), Eriksson and Westerberg (2009) and Eriksson and Vennstrom (2009) suggest different procurement related factors that can affect project performance. These studies considered different procurement related factors without an area of commonalities. According to Hashim (1999) preconstruction time, control of project design and cost and client's control of construction projects are procurement related factors whose influences were found on procurement methods of Traditional, Design and Build and Management Contracting in Malaysia construction industry. Studies of Rasid et al. (2006) also in Malaysia concentrated on allocation of responsibilities, activities sequencing, process and procedure and organizational approach as procurement related factors that affect project performance. Eriksson and Westerberg (2012) indicates important procurement related factors considered at the design stage as bid invitation, bid evaluation, sub- contracting selection, compensation factors and performance evaluation which were termed collaborative procurement procedures were found to have effects on project performance. Eriksson and Vennstrom (2012) also postulate that cooperative procurement procedures of joint specification, limited bid invitation, softevaluation parameters, joint sub-contractor selection, incentives, collaborative tools, contractor self control and collaboration on project all have various effects on project performance. Procurement related factors identified from these previous studies are also related to selection criteria, tendering methods and variation orders that are considered in this study. Some of these procurement related factors are in ambit of what has been considered in previous studies and hence they are discussed as follows:

\section{Procurement Selection criteria}

Different authors have postulated different procurement selection factors that can assist clients to choose the best procurement method. Studies of Masterman and Gameson (1994), Rowlinson (1999), Alhazini and McCaffer (2000), Shiyamni et al. (2006) as cited in Soyombo and Ogunsanmi (2011) have demonstrated that procurement selection factors of client characteristics, project requirements and external environment are in use. However, Shiyamni et al. (2006) re-emphasized the use of the three factors together but expansively considers client requirements to include cost related factors, time related factors and quality related factors. Several variables of client requirements were measured under cost, time and quality related factors. Project characteristics factors also include project type, size, cost, flexibility, complexity, site risk factors and degree of innovative technology. External environment factors considered are market competitiveness, availability of materials, natural disasters, industrial actions amongst other variables. Client characteristics, project requirements and external factors are considered with general needs for investigating the procurement related factors that affect project performance in this study. Cost related factors of capital cost of the project, maintenance cost, prequalification cost, financial risk amongst other variables can influence a client to select a particular procurement method that meets all these client requirements. Time related factors of 
planning and design time, construction time, early start of project, speed of construction and time overrun can help client to select an appropriate procurement method. Quality related factors of design reliability, aesthetic appearance of the building, workmanship amongst other variables are considered in this study. General needs factors of involvement of parties, their transparency, accountability, safety requirements and flexibility of the procurement process to client charges are also considered in the study. Project characteristics factors considered in this study are project type, size, cost, degree of flexibility, complexity, time constraints, payment method, finding methods and innovative technology. Moreover, external environment factors considered also include nature of the market, government policies, government as major client, regulating feasibility, technology feasibility amongst other variables. All these above factors can influence the selection of an appropriate procurement method that can also affect project performance.

\section{Tendering Method Related Factors}

Tendering is the administrative procedure of sending out drawings and bill of quantities or specification to contractors with the intention to submit a price for the construction of the project. Besides the price for this project other consideration such as contractor's competence, financial capability, technical competence and other factors are used in selecting a contractor for executing a construction project. Different tendering methods have been used in construction projects for inviting tenders. According to Ramus (1981), Manthosi and Thawala (2012) and Ganderton (2012) there are various methods such as open selective, negotiation, competitive, openselective, design and build tendering approaches that have been used in construction projects. In addition, serial and two-stage tendering methods have been significantly used also in construction projects. According to Mathonsi and Thawala (2012) the use of open tendering method involves placing an advertisement in a widely read newspaper to invite prospective contractors to tender and it is strongly criticized for its increased cost of processing. Selective tendering in the views of Ramus (1981) involves considering 5-8 competent contractors to be invited to tender for a project. Criteria used in drawing up these competent contractors can include standard of workmanship required, equipment base of the firm, previous business records and financial standing amongst other factors. Selection of contractor through this approach may overcome the deficiencies in open tendering but may lead to higher quotations. Negotiation approach is used when a firm or client has previous satisfaction association with a contractor and the client is prepared to give the contract to this contractor on bases of reasonable price for the project. Such an arrangement is also used if the project is of specialist nature. This approach is known to save time but may lead to higher prices for the quotation (Ramus, 1981; Ganderton, 2012). Competitive tendering approach is used where various contractors of all categories are welcomed to submit tenders. According to Chinyio (2011) competitive tendering must have three stages of (1) pre-qualification, (2) tender documentation and (3) bidding.

As indicated by Public Procurement Act (2007) competitive tendering in Nigeria is to encourage due process, accountability and transparency but this involves high bidding cost, conflicts of interest as it is not guaranteed that the lowest tender wins the project. Open-selective tendering approach is used as a hybrid of open and selective methods. The Traditional procurement method utilizes open, selective and negotiated tendering approaches to obtain its tenders (Mathonsi and Thawala, 2012). Design and build procurement method utilizes selective tendering method for obtaining tenders from Design-build contractors. According to Chinyio (2011) selective tendering method can be sub-divided into singlestage and two-stage tendering methods. Single stage tendering is an approach where one stage of tendering is used while a two-stage tendering method involves a two-stage process of competitive selection of contractor on basis of price and negotiation of contract details and firm price with the contractor appointed at the first stage. On the first stage contractors will be assessed on basis of construction programmes, method statements, pricing of preliminaries, overheads and profits. In the second stage negotiation between the client and the contractor on price is undertaken. If agreed it becomes the contract price (Chinyio, 2011). This approach is advantageous in that it facilitates early appointment of a contractor and it combines 
strengths of competition and negotiation while its disadvantage is that the preferred contractor may fail to negotiate for the competitive price and negotiation may drag-on and compound the complexity of the process. All these discussed tendering approaches in this section are exploited for this study. Tendering approaches that are used for selecting a contractor for a project can affect project performance. If the tendering procedure used is such that focuses on low tender price, this may result in increased risk of cost overrun on the project due to high cost of variation orders (Assaf and Al-Heiji, 2006). As stretched by Iyer and Jha (2005) as cited in Soyombo and Ogunsanmi (2011) there is a need to be careful of contractor selection on projects as to reduce cost growths.

\section{Variation Order Related Factors}

In almost all construction projects contracts are the contractual clauses allowing parties involved in the contract to freely initiate variation orders (Ndihokubwayo and Haupt, 2009). Variation order has been seen by many studies as involving additions, omissions, alterations and substitution in terms of quality, quantity and schedule of works (Al-Jishi and Al-Marzoug, 2008; Mohammed, Ani, Rakmat and Yusof, 2011; Ndihokubwayo, 2008; 2009; Rodriguez, 2012). In all these studies various reasons have been advanced for the causes of variation orders but the studies of Ndihokubwayo (2008; 2009) have been crystal clear that variation orders occur due to reasons of finance, design, aesthetic, geological, weather conditions, feasibility of construction, statutory changes, product improvement and discrepancies between contract documents. These studies indicate that because human behaviour of parties to the contracts is unpredictable it may result in variation order arising from changes in minds of parties involved in the contract. Variation orders may be initiated by client, contractors or consultants as the case may be.

Variation order has been identified in the main to have two main types as beneficial and detrimental variation orders. Beneficial variation order is one issued to improve quality standard, reduce cost, schedule or degree of difficulty in a project while detrimental variation order is one issued that negatively impacts the client's value or project performance. Variation orders are inevitable in most types of projects and Ndihokubwayo and Haupt (2009) has indicated that for inclusion of variation clauses in contracts amounts to admitting that no project can be executed without changes. Variation orders are procurement related factors that are explored in the present study to find out its impacts on project performance. Impact of variation orders on project performance can be noted in the works of Ndihokubwayo and Haupt (2009), Al-Jishi and AlMorzoug (2008) and Enshassi, Arain and Al-Raee (2011). Ndihokubwayo and Haupt (2009) states that there are various studies which revealed that variation orders contribute to both cost and project time overruns. Al-Jishi and Al-Marzoug (2008) indicates that variation order can cause impact of additional money for the contractor on the project, delay of materials and tools, work on hold among others while Enshassi, Arain and Al-Raee (2011) indicates that in the Gaza Strip variation orders result in time delay, cost overrun, quality defects and other negative impacts. All these discussed impacts of variation orders on project performance are investigated in this study.

\section{Research Methods}

Literature review was undertaken to identify procurement selection criteria factors, tendering methods and variation order factors that can impact on project performance. A structured questionnaire was designed to collect information on procurement selection factors that sought for the effects of procurement selection factors on project performance. The population of the study consisted of Architects, Builders, Engineers and Quantity Surveyors who have been involved in some recent procurement in the Nigerian construction industry. Snowballing sampling technique was used for selecting the sample. In all, forty (40) firms were selected in Lagos metropolitan city and questionnaires were sent out to the various respondents in these organizations. Thirty-one (31) questionnaires were retrieved from these respondents that were used for the data analysis. Descriptive statistical tools inform of Tables and mean item score as well as inferential statistical tools of chi-square and Analysis of Variance were used for the analysis of the data collected from the respondents. 
Results and Discussions

Effects of Procurement Selection Criteria on Project Performance

Table 1 shows that of the six procurement selection criteria that show some effects on project performance cost related factors ranks first (MIS = 0.89 ), time related factors ranks second (MIS = 0.85 ), quality related factors ranks third (MIS = 0.77) while project characteristics ranks sixth
(MIS= 0.71). These results also reveal that cost related factors has the highest impact on project performance while time and quality related factors show some level of impacts on project performance. General needs, external environment and project characteristics do not show too serious impacts on project performance. Emphasis is still on cost, time and quality effects for selecting procurement method.

Table 1 Descriptive Result of Effects of Procurement Selection Criteria on Project Performance

\begin{tabular}{lll}
\hline Procurement Selection Criteria & $\begin{array}{l}\text { Mean item } \\
\text { (MIS) }\end{array}$ & Overall ranking \\
\hline Cost related factors & 0.89 & $1^{\text {st }}$ \\
Time related factors & 0.85 & $2^{\text {nd }}$ \\
Quality related factors & 0.77 & $3^{\text {rd }}$ \\
General needs & 0.74 & $5^{\text {th }}$ \\
Project characteristics & 0.71 & $6^{\text {th }}$ \\
External environment & 0.76 & $4^{\text {th }}$ \\
\hline
\end{tabular}

Table 2 Inferential Results of Effects of Procurement Selection Criteria on Project Performance

\begin{tabular}{lllllll}
\hline Procurement selection criteria & $\mathrm{X}^{2}$ cal & Dif & $\mathrm{X}^{2}$ tab & P-value & Sig. & Decision \\
\hline Cost related factors & 31.83 & 3 & 9.34 & 0.00 & $\mathrm{~S} *$ & Accept $\mathrm{H}_{1}$ \\
Time related factors & 16.61 & 3 & 9.34 & 0.00 & $\mathrm{~S}^{*}$ & Accept $\mathrm{H}_{1}$ \\
Quality related factors & 20.45 & 4 & 11.14 & 0.00 & $\mathrm{~S} *$ & Accept $\mathrm{H}_{1}$ \\
General needs & 1.38 & 3 & 9.34 & 0.70 & $\mathrm{NS}$ & ${\text { Accept } \mathrm{H}_{0}}^{*}$ \\
Project characteristics & 20.13 & 3 & 11.14 & 0.00 & $\mathrm{~S} *$ & Accept $\mathrm{H}_{1}$ \\
External environment & 9.38 & 4 & 9.34 & 0.02 & $\mathrm{~S}^{*}$ & Accept $\mathrm{H}_{1}$ \\
\hline
\end{tabular}

Table 2 also shows that cost, time, quality project characteristics and external environment procurement selection factors have their calculated chi-square values $\left(\mathrm{x}^{2}\right.$ cal $=31.83,16.61,20.45$, $20.13,9.39)$ higher than the tabulated values $\left(x^{2}\right.$ $\mathrm{tab}=9.34,11.14$ ) hence the results are significant. This implies accepting the alternative hypothesis. This indicates that cost, time, quality, project characteristics and external environment have effects on project performance. Similarly, general needs has its calculated chi-square value $\left(x^{2}\right.$ cal $=1.38)$ lower than the tabulated value $\left(\mathrm{x}^{2}\right.$ tab $=$ 5.98) hence the results is not significant. This also implies accepting the null hypothesis. This infers that general needs have no effect of project performance. These results agree with the descriptive results in Table 1 and generally it can be inferred that cost, time, quality, project characteristics and external environment selective criteria impact on project performance. These results are also in agreement with Shaban and
Enshassi (2008) findings in which significant degree of agreement were found between owners, consultants and contractors as to effects of cost, time quality, productivity, clients' satisfaction, people, innovation on project performance in the Gaza Strip. These key performance indicators (KPI) were analyzed for project performance in the Gaza Strip and were found to affect project performance in various ways.

\section{Effects of Tendering Method Related Factors on Project Performance}

From the results presented in Table 3 it is shown that competitive tendering $(\mathrm{RIF}=0.78)$ has a very high impact on project performance as it ranks first, selective tendering $(\mathrm{RIF}=0.77)$ also has a very high impact on project performance as it ranks second, open tendering method and negotiated tendering method $(\mathrm{RIF}=0.76)$ both rank third and also have high impacts on project performance. 
Table 3 Descriptive Results of Effects of Tendering Method Related Factors on Project Performance

\begin{tabular}{lll}
\hline Tendering method factors & Relative Impact Factor & Overall Ranking \\
\hline Competitive tendering & 0.78 & $1^{\text {st }}$ \\
Open tendering & 0.76 & $3^{\text {rd }}$ \\
Selective tendering & 0.77 & $2^{\text {nd }}$ \\
Open selective tendering & 0.68 & $7^{\text {th }}$ \\
Design and build tendering method & 0.68 & $7^{\text {th }}$ \\
Turnkey tendering method & 0.68 & $9^{\text {th }}$ \\
Serial tendering & 0.71 & $6^{\text {th }}$ \\
Negotiated tendering & 0.76 & 3 th \\
Two stage tendering method & 0.73 & $5^{\text {th }}$ \\
\hline
\end{tabular}

Turnkey tendering method $(\mathrm{RIF}=0.65)$ ranks ninth and it has very low impact on project performance. The above results demonstrate that the type of tendering methods used in a procurement method can influence the performance of the method. In Nigeria construction industry the use of competitive, selective, open and negotiated tendering methods have impacted on the performance of most projects in the country and this is the more reason why the Nigerian Public Procurement Act (2007) promotes the use of these above tendering methods for procurement of construction projects in Nigeria.

From the results presented in Table 4 it shows that the calculated F-value $\left(\mathrm{F}_{\mathrm{cal}}=0.75\right)$ is quite lower than the tabulated value $\left(\mathrm{F}_{\mathrm{tab}}=1.94\right)$ hence the result is not significant. It supports the null hypothesis and hence it is accepted. It implies that there is no significant difference between the impacts of the tendering methods on project performance. Each of the tendering methods has equal impacts on project performance.

\section{Effects of Variation Order Related Factors on} Project Performance

Results in Table 5 indicates that time overrun (RII=0.89) which is an effect of variation order on project performance ranks first, cost overrun (RII $=0.85$ ) another effect of variation order on project performance ranks second, disputes between parties to the contract $(\mathrm{RII}=0.79)$ ranks third while complaints of parties to the contractor (RII = $0.65)$ ranks eleventh. These results demonstrate that variation orders have effects on project performance. These descriptive results agree with the findings of Ndihokubwayo (2009) in which time and cost overruns as well as disputes between parties to the contract rank first, second and third in a research project conducted in South Africa. From the results presented in Table 6 it is shown that calculated F-value $\left(\mathrm{F}_{\text {cal. }}=4.29\right)$ is quite higher than the tabulated F-value $\left(\mathrm{F}_{\mathrm{tab}}=2.70\right)$ hence the result is significant. This supports the alternative hypothesis and hence is accepted. This implies that variation orders factors have significant effects on project performance. Studies of Ndihokubwayo and Haupt (2009), Ndihokubwayo (2008), Al-Jishi and Al-Morzoug (2008) and Enshassi et al. (2011) all confirm the above results that variation orders have effects on project performance. In particular, Ndihokubwayo and Haupt (2009) identified cost and time overruns, productivity losses, poor quality of jobs, health and safety problems and disputes as negative effects of variation orders on project performance. 
Table 5 Descriptive Results Effects of Variation Order Related Factors on Project Performance

\begin{tabular}{lll}
\hline $\begin{array}{l}\text { Effects of variation order factors on project } \\
\text { performance }\end{array}$ & $\begin{array}{l}\text { Relative Impact Index } \\
\text { (RII) }\end{array}$ & $\begin{array}{l}\text { Overall } \\
\text { ranking }\end{array}$ \\
\hline Time overrun & 0.89 & $1^{\text {st }}$ \\
Cost overrun & 0.85 & $2^{\text {nd }}$ \\
Disputes between parties to the contractor & 0.78 & $3^{\text {rd }}$ \\
Additional specialist equipment/personnel & 0.73 & $8^{\text {th }}$ \\
Complaints of parties to the contract & 0.65 & $11^{\text {th }}$ \\
Quality standard enhanced & 0.74 & $6^{\text {th }}$ \\
Professional reputations of parties adversely affected & 0.74 & $7^{\text {th }}$ \\
Degradation of quality standards & 0.77 & $4^{\text {th }}$ \\
Optimum cost reduction & 0.71 & $10^{\text {th }}$ \\
Degradation of health and safety & 0.73 & $9^{\text {th }}$ \\
Time reduction & 0.76 & $5^{\text {th }}$ \\
\hline
\end{tabular}

Table 6 ANOVA Results of Difference in Impact between the Variation Orders Factors on Project Performance

\begin{tabular}{llllllllll}
\hline Source of variation & $\begin{array}{l}\text { Sums } \\
\text { square }\end{array}$ & of & $\begin{array}{l}\text { D.F } \\
\end{array}$ & $\begin{array}{l}\text { Mean } \\
\text { square }\end{array}$ & $\mathbf{F}_{\text {cal }}$ & $\mathbf{F}_{\text {tab }}$ & Sig & P-value & Decision \\
\hline Between groups & 5.50 & 3 & 1.84 & 4.29 & 2.70 & $\mathrm{~S}^{*}$ & 0.00 & \\
Within groups & 41.66 & 96 & 0.43 & & & & & \\
Total & 47.16 & 99 & & & & & & \\
\hline
\end{tabular}

\section{Conclusions}

In view of the findings of this study the following conclusions are deduced from the study: There are various factors affecting project performance emanating from procurement selection criteria, tendering methods and variation order factors. Cost, time and quality procurement related selective factors have demonstrated strong conditions for selection of any procurement method and have also influenced the performance of such construction projects. The way a project is tendered for can affect its performance. Several approaches of tendering allowing new comers, selecting from existing performing vendors and approaches allowing contractors to compete with each other have resulted in successful construction projects. Variation orders have impacted project performance in various ways. It has caused construction projects to have time and cost growths and serious disputes have resulted between parties to contracts. Recommendations include that clients, stakeholders, practitioners as well as consultants on projects should give careful consideration to the tendering method to be adopted when selecting a procurement method and when project is on-going, clients should order fewer variations on the project as this can affect the success and cause cost growths for the projects. Selective, open and competitive tendering methods are recommended to clients, consultants and practitioners for use in their construction project bidding as these methods are known to give successful projects. Policy makers in government, clients, and private developers into housing projects should give adequate attention for selecting appropriate procurement and tendering methods for better management of future projects in Nigeria and other developing countries.

\section{References}

Al-Jishi, S. and Al-Marzoug, H. (2008), "Change orders in Construction Projects in Saudi-Arabia." Construction Engineering and Management Department Term Paper, King FahD University of Petroleum and Minerals, Saudi Arabia.

Assaf, S.A. and Al-Heiji, S. (2006), Causes of Delay in Large Construction Projects. Journals of Project Management, 24, 349-307.

Chinyio, E. (2011), The cost of Tendering. In Toole, T.M. (Ed), Working paper Proceedings of Engineering Project Organizations Conference held in Estes Park, Colorado, U.S.A, August 9-11. Dada, M.O. (2012), A second look: Stakeholders' Perceptions of Some Issues in Design - Bid-Build 
Procurement Practice in Nigeria. Journal of Sustainable Development, 5(1), 55-63.

Enshassi, A., Arain, F. and Al-Raee, S. (2010), Causes of Variation Orders in Construction Projects in the Gaza Strip. Journal of Civil Engineering and Management, 16(4), 540-541.

Erksson, P. and Westerberg, M. (2012), Effects of Procurement on Construction Project

Performance, Retrieved on $25^{\text {th }}$ October, (2012)

from<http://www.pure.itas/portal/files/3477530/Pr ocurement_related_success=factors_effect_on_pro ject_performnce_submitted_IAMT.pdf.

Erksson, P. and Vennstrom, A. (2012), Effects of Procurement on Project Performance. A Survey of Swedish Construction Clients. Retrieved on $25^{\text {th }}$ October, (2012) from <http://www. pure.itase

/portal/files/3477530/Procurement_related_succes s=factors_effect_on_project_performnce_ubmitted _IAMT.pdf.

Ganderton (2012), Define Tenders and types of tender? Retrieved on $28^{\text {th }}$ October, 2012

from<http://wikianswers.com/0/Define tender and types of tender\# page 2 .

Hashim, M.B. (1999), "The Effects of Procurement Methods on Performance of Construction Projects in Malaysia". An Unpublished P.hD Thesis of University Technologi Malaysia, Faculty of Built Environment, Malaysia.

Mathonsi, M.D. and Thwala, W.D. (2012), Factors Influencing the Selection of Procurement Systems in the South African Construction Industry. Africa Journal of Business Management, 6(10), 35833594.

Mohammad, N. Ani, A.I. Rakmat, R.A. and Yusuf, M.A. (2010), Investigation of the Causes of Variation Orders in the Construction of Building Project - A study in the State of Selangor, Malaysia. Journal of Building Performance, 1 (1), 73-82.

Ndihokubwayo, R. (2008), An Analysis of the Impact of Variation Orders on Projects Performance, CPUT Thesis and Dissertations, Papers 33, Retrieved on $28^{\text {th }}$ October, 2012 from<http://dk.cput.ac.za/td_cput/33.

Ndihokubwayo, R. and Haupt, T. (2009), Variation Orders of Construction Projects: Value
Adding or Waste? International Journal of Construction Project Management, IJCPM, 1(2), 1-17.

Ogunsanmi, O.E., Iyagba, R.O.A. and Omirin, M.M. (2003), A comparative Study of the Performance of Traditional and Labour only Procurements in Nigeria. Journal of Nigeria Institute of Building, 12-27.

Ojo, S.O. Adeyemi, A. Y. and Fagbenle, O. (2006), The Performance of Traditional Contract Procurement in Housing Projects in Nigeria. Civil Engineering Dimension, 11 (2), 106-102.

Public Procurement Act (2007), Procurement Procedures Manual for Public Procurement in Nigeria, Bureau of Public Procurement, Abuja, FCT, Nigeria.

Ramus, J.W. (1989), Contract Practice for Quantity Surveyors. London: Heinemann Publishers, Limited.

Rasid, R.A. Taib, I.M. Ahmad, W.B., Nasid M.D., Ali, W.N.and Zainordin, Z.M. (2006), Effect of Procurement Systems on the Performance of Construction Projects. Proceeding of International Conference on Construction Industry, held in Padang, Indonesia, June $21^{\text {st }}-24^{\text {th }}$ (pp1-13). Retrieved on $25^{\text {th }}$ October 2012 from<http://eprints.utm.my/790/1/procurement_pe rformance Rosli.pdf.

Rodriguez, J. (2012), Common Causes for a change order. Retrieved on $20^{\text {th }}$ October 2012 from

http://construction.about.com/od/claims.managem ent/a/common causes. For.A. change.order.htm.

Shaban, S.S. and Enshassi, A. (2008), "Factors Affecting the Performance of Construction Projects in the Gaza Strip". An Unpublished M.Sc Thesis of Faculty of Engineering Construction Management Department, The Islamic University of Gaza, Palestine.

Soyombo, O.A. and Ogunsanmi, O.E. (2011), "Evaluation of the Impact of Procurement Systems on Project Outcome". An Unpublished M.Sc. Dissertation of the Department of Building, University of Lagos, Lagos. 